sciendo Zagreb International Review of Economics \& Business, Vol. 21, Special Conference Issue, pp. 1-14, 2018

(C) 2018 Faculty of Economics and Business, University of Zagreb and De Gruyter Open

All rights reserved. Printed in Croatia

ISSN 1331-5609; UDC: $33+65$

DOI: 10.2478 /zireb-2018-0020

CONFERENCE PAPER

\title{
When Consumers are in Doubt, You Better Watch Out! The Moderating Role of Consumer Skepticism and Subjective Knowledge in the Context of Organic Food Consumption
}

\author{
Merima Činjarević * \\ Emir Agic * \\ Almir Peštek*
}

Abstract: Despite numerous scholarly attempts, there is a lack of consensus regarding the relevance of various factors influencing consumer's intention to purchase organic food. The purpose of this study is to asses the impact of subjective and personal norms on consumer attitude toward buying organic food. Moreover, this study aims to explore the moderating role of contextual factors - product knowledge and consumer scepticism on the norms- attitude link. Data were collected through an online survey on a sample of 212 organic food buyers in Bosnia and Herzegovina. Moderated regression analysis was used to test the hypothesized relations between the constructs of interest. Findings indicate the subjective and personal norms are positively and significantly related to consumer attitude toward organic food purchases. Also, our findings revealed that product knowledge strengthens the subjective norms-attitude relationship, while consumer scepticism toward organic food claims weakens the subjective norms-attitude link. This study informs producers, marketers, and policy-makers about the relative importance of norms, scepticism, and knowledge in the context of organic food consumption.

Keywords: Subjective norms; Personal norms; Consumer skepticism; Subjective knowledge; Organic food

JEL Classification: M31

\footnotetext{
* Merima Činjarević, Emir Agić and Almir Peštek are at School of Economics and Business, University of Sarajevo, Sarajevo, Bosnia and Herzegovina.
} 


\section{Introduction}

There is widespread consensus that environmentally and socially sustainable food production is needed to tackle future challenges, such as the degradation of natural resources, the loss of biodiversity and the on-going rural depopulation (Meyer-Höfer, Nitzko \& Spiller 2015). Thus, organic food production systems are seen as one possible solution to these problems (Padel \& Foster, 2005; Thøgersen, 2009). Moreover, the increasing health awareness and concern about sustainability issues in consumption among consumers and citizens have led to the rise of organic consumerism, particularly in the context of organic food consumption.

The European market for organic food has grown tremendously during the past few decades (Willer \& Lernoud, 2017). The leading EU countries regarding retail sales were Germany ( 8.6 billion euros), France (5.5 billion euros), United Kingdom ( 2.6 billion euros), Italy, (2.3 billion euros), and Switzerland (2.2 billion euros). While these markets have reached maturity, other markets (e.g., Western Balkan countries) are still in the early stages of the development (Alibabić et al., 2011; Cerjak et al., 2010; Petljak, Štulec \& Renko, 2017).

Table 1: Organic food market in Western Balkan countries compared to EU-28

\begin{tabular}{|l|c|c|c|c|c|c|}
\hline & EU-28 & AL & BA & MK & RS & ME \\
\hline Organic agricultural land 2014 (ha) & $10,250,742$ & 515 & 353 & 3,146 & 9,548 & 3,289 \\
\hline Share of total agricultural land 2014 (\%) & 5.7 & 0.04 & 0.02 & 0.3 & 0.2 & 0.6 \\
\hline Number of organic producers 2014 & 257,525 & 39 & 24 & 382 & 1,281 & 167 \\
\hline Total organic sales (Mio €, 2014) & 23,943 & na & 1,7 & na & na & 0,1 \\
\hline Total organic sales 2014 (€/person) & 47.4 & na & 0,4 & na & na & 0,2 \\
\hline $\begin{array}{l}\text { Note: na, not avilable } \\
\text { AL - Albania; BA - Bosnia and Herzegovina; MK - Macedonia; RS - Serbia; ME- Montenegro. }\end{array}$
\end{tabular}

Source: Own compilation according to Willer and Lernoud (2017)

Table 1 shows the current figures for organic food production and consumption in the Western Balkan countries compared to the EU-28. Due to the different stages of organic food market development in EU countries and Western Balkan countries, it is lucrative to conduct a study focusing on organic food consumption within a market that is still in its infancy.

Previous studies have applied various theories to better understand consumer behavior in the context of organic food consumption. Theory of Planned Behaviour (TPB), proposed by Ajzen (1991), has been applied successfully to explain a wide range of human behavior based on their behavioral intention. TPB assumes that behavioural intention can be predicted by three motivational factors: (1) the individual's attitude toward engaging in the behaviour; (2) the degree of social pressure felt by the person with regard to the behaviour (subjective norms); and (3) the degree to which 
the behaviour is personally controllable (perceived behavioural control). Additional theories, such as Norm-Activation Model - NAM (Schwartz, 1977) and Attitude Behaviour Context Model - ABC (Guagnano, Stern \& Dietz, 1995) emphasize the role of personal norms and contextual/situational factors in explaining consumer buying behavior. Anchored in these three theories (TPB, NAM, and ABC), this study aims to examine how subjective and personal norms are shaping consumer's attitudes toward organic food purchases in a novice market context (i.e., Bosnia and Herzegovina). Also, this study strives to test the moderating role of subjective knowledge about organic food and consumer scepticism with the regard of organic food claims on the relationship between norms (subjective and personal) and consumer attitude toward organic food purchases.

The paper is organized as follows. First, we describe the theoretical background and hypotheses development. Next, we detail the research design, data analysis, and results. Finally, we discuss findings along with limitations and future research directions.

\section{Theoretical Background and Hypotheses}

Subjective norms refer to the person's perception of the social pressures associated with the decision to either perform or not perform the behavior (Ajzen, 1991). Two components determine subjective norms: normative beliefs (what a person thinks others would want or expect from her/him to do) and motivation to comply with them (how important is it to the person to do what she/he thinks others expect). Previous studies confirm that subjective norms play a pivotal role in influencing consumer behavior regarding organic food (e.g., Tarkiainen \& Sundqvist, 2005; Thøgersen, 2009; Zagata, 2012). Tarkiainen and Sundqvist (2005) assert that positive or negative attitude toward buying organic food tend to "pass on" among people. Therefore, if consumers believe that those people important to them think organic food is good, then they will be more prone toward buying organic food. On the contrary, if consumers believe that those people important to them think organic food is worse than non-organic food, then they will have less prone to buy organic food. Hence, we derive the following hypothesis:

H1: Social norms have a positive impact on consumer attitude toward buying organic food.

Personal norms can be defined as the feeling of moral obligation to act by an individual's own value systems (Schwartz, 1977). The central feature of personal norms is that these norms represent the internalization of subjective norms. It has been shown, for instance, that compliance with personal norms is associated with 
feelings of pride, while noncompliance with personal norms is related to feelings of guilt (Onwezen, Antonides \& Bartels, 2013). According to the Norm-Activation Model (Schwartz and Howard, 1981), personal norms are activated by an awareness of need - feeling that action is necessary to prevent a negative outcome for nature, and an awareness of consequences - an awareness that the individual's actions affect nature positively or negatively). The role of moral norms or values in motivating organic food purchases has been the subject of vigorous debate. However, many scholars argue that personal norms have a significant influence on consumer attitude and their intention to buy organic food (Aertsens et al., 2009; Arvola et al., 2008; Klöckner \& Ohms, 2009; Thøgersen, 2002). Klöckner and Ohms (2009), for instance, examined the link between personal norms and observed purchase behavior of organic milk. They found that people with strong personal norms exhibit a different pattern of decisional criteria with the regards to organic food purchases. More precisely, they found that people with strong personal norms use "organic production," the "EU-BIO-Label" and "ingredients" as additional criteria during their decision process. Therefore, we formulate a hypothesis for the direct effect of personal norms on consumer attitude toward buying organic food:

\section{H2: Personal norms have a positive impact on consumer attitude toward buying organic food.}

Consumer attitude consists of attitude valence and attitude strength. Attitude valence refers to the degree of positivity or negativity by which an attitude object (in the current context, a buying organic food) is evaluated. On the other hand, attitude strength is ,the positivity or negativity (valence) of an attitude weighted by the confidence or certainty with which it is held" (i.e., the extent to which it is considered valid) (Park et al., 2010). According to the integrated information theory, attitudes are formed and changed through the integration (mixing, combining) of new information existing cognitions or thoughts. Therefore, related contextual factors, such as consumer's knowledge about organic food and scepticism toward marketing/advertising claims about organic food, could influence the norms-attitude link (Golob, Kos Koklic, Podnar \& Žabkar, 2018) In this study, we assume that product knowledge and consumer scepticism are contextual factors that can shape the relationship between norms and consumer attitude toward buying organic food.

Product knowledge is a multidimensional construct involving the familiarity and expertise the consumer has with a product. There are three distinct types of product knowledge, including subjective product knowledge, objective product knowledge, experience-based product knowledge (Bruck, 1985). Previous studies have shown that subjective knowledge is more strongly associated with behavior than actual (objective) knowledge (Pieniak, Aertsens \& Verbeke, 2010). Thus, the present study emphasizes the subjective knowledge about organic food. If consumers have more knowledge about organic food, they will rely more on themselves to form attitudes 
toward buying organic food rather than to depend on beliefs/attitudes created by reference group members. Opposite, when consumers have less knowledge about the organic food they have less confidence in themselves, and they are inclined to accept the attitudes of other reference group members. Thus, this study proposes the following hypotheses:

H3a: The effect of subjective norms on consumer attitude toward buying organic food will be greater when consumers have a low level of subjective organic food knowledge than when they have a high level of subjective organic food knowledge.

H3b: The effect of personal norms on consumer attitude toward buying organic food will be greater when consumers have a high level of subjective organic food knowledge than when they have a low level of subjective organic food knowledge.

Scepticism refers to "a person's tendency to doubt, disbelieve, or question" (Skarmeas \& Leonidou, 2013, p.1832). There is an on-going debate regarding the nature of scepticism. While some researchers argue that scepticism is a personality trait (e.g., Obermiller \& Spangenberg, 1998; Skarmeas \& Leonidou, 2013), the majority of researchers agree that scepticism is a temporary consumer state induced by situational factors (e.g., Goh \& Balaji, 2016). In the present study, "scepticism" is used to refer to situational scepticism brought about by the claims made in marketing messaging regarding organic food. Due to numerous scandals related to dioxin, genetically modified foods and overuse of prohibited food additives in food production, many consumers have become sceptical towards products which are promoted as "organic," "bio" or "natural." Indeed, Hughner et al. (2007) showed that scepticism of organic labels is one of the deterrents for purchase intention of organic food. Moreover, it was found that consumer scepticism leads to adverse product judgment, unfavorable attitude toward a product and lower purchase intentions (Kaj \& Pruyn, 2003). Thus, consumer scepticism can moderate the effect of the subjective and personal norms on consumer attitude toward buying organic food. Specifically, low consumer scepticism can enhance the impact of subjective and personal norms on consumer attitude toward buying organic food, while high consumer scepticism can weaken the norms-attitude link. Thus, this study hypothesizes the following:

H4a: The effect of subjective norms on consumer attitude toward buying organic food will be greater when consumers have a low-level of organic food scepticism than when they have a high level of organic food scepticism.

$H 4 b$ : The effect of personal norms on consumer attitude toward buying organic food will be greater when consumers have a low-level of organic food scepticism than when they have a high level of organic food scepticism. 
Figure 1: Conceptual framework

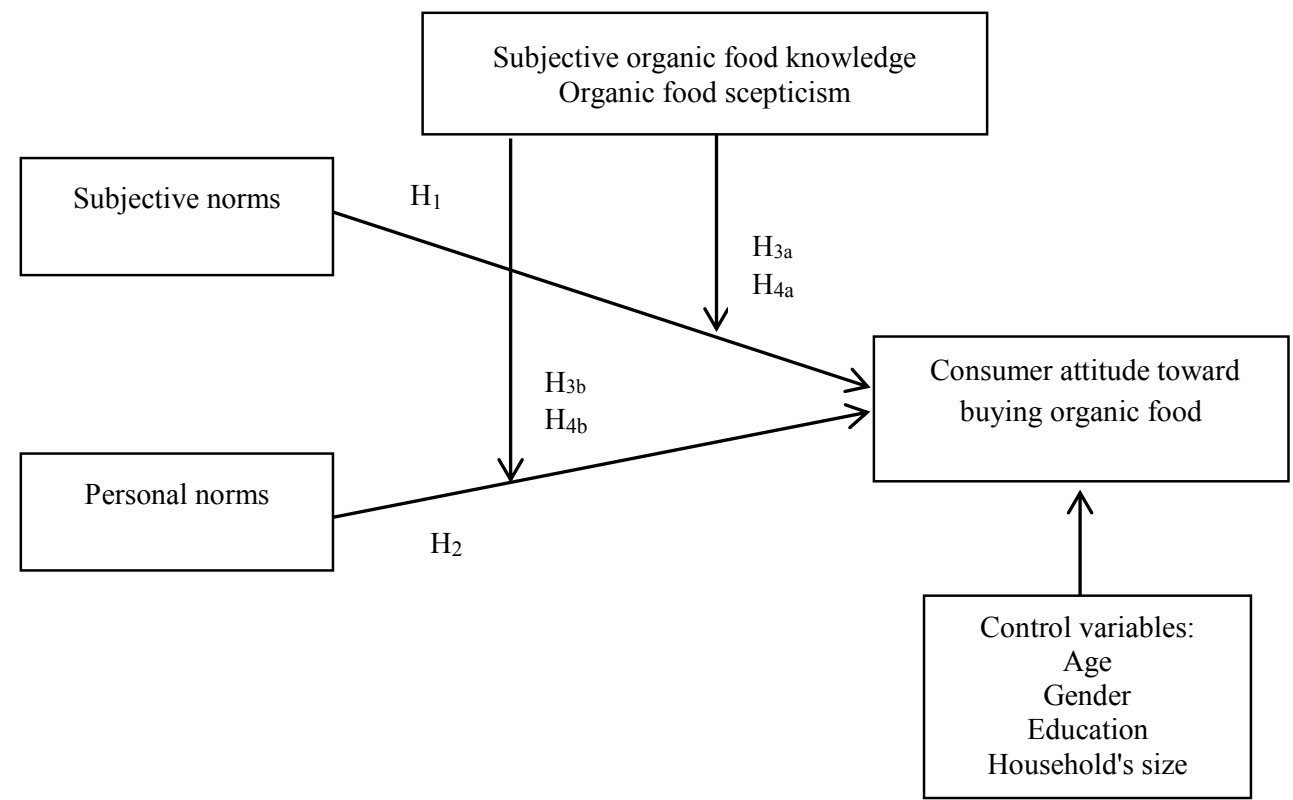

In summary, the conceptual framework (Figure 1) encompasses the following major points. First, the model includes the direct effects of two types of norms (i.e., subjective and personal) on consumer attitude toward buying organic food. Second, the model incorporates the interaction effects of two variables, subjective organic food knowledge, and organic food scepticism. Third, the model compromises the gender, age, education, and size of the household as control variables. Studies extensively specify and explain that age, gender, income, size of the household can influence consumer attitude toward a buying organic food. Thus, we controlled these variables within the model.

\section{Research Methodology}

\section{Measures}

This study adopted its measures from well-established scales. Subjective norms are captured in line with Ajzen and Fishbein (1980), by measuring the extent to which individual's decisions to purchase organic food are affected by the opinions of his or her family members, friends, and others. For personal norms, this study employs two items from the scale developed by Hynes and Wilson (2016). Organic food subjective knowledge was measured using five-item scale proposed by Flynn and Goldsmith 
(1999). The items used to measure organic food scepticism were adapted from Goh and Balaji (2016) and modified to fit the context of organic food. Consumer attitude toward buying organic food was captured by a scale developed by Yazdanpanah and Forouzan (2015). All items were measured on a 7 point-Likert scale ranging from 1 - "strongly disagree" to 7 - "strongly agree". Additionally, the questionnaire included socio-demographic variables (gender, age, employment status, monthly income, education, household size), each measured via a categorization scheme.

\section{Data Collection}

The questionnaire is created and distributed through the Lime Survey service. Since online survey carries the risk of targeting the wrong group of participants, the text on the welcome page stated that this survey is intended to be filled in by the person who meets specific inclusion criteria. For this survey, we set the following inclusion criteria: (1) age of at least 18 years,; (2) sole/joint responsibility for grocery shopping; and (3) purchase of organic food in the past six months. Due to budget constraints and the risk of introducing some form of bias into the results, no incentives were used to solicit survey participation. A one-week follow-up with a second wave of mailings resulted in a total of 212 responses. However, due to missing values, 184 responses were usable. The sample is an unbalanced mix of females (73.1\%) and males (26.9\%). This disproportion of male and female participants is typical for a study of consumer behavior in the domain of daily grocery shopping (Klöckner \& Ohms, 2009). Most respondents are young, aged between 18 and 34 years (49.2\%). The majority of the respondents (69.9\%) reported a bachelor or master degree as their level of education. Regarding income, $71.9 \%$ of respondents have monthly household income below 1.500 EUR and $29.1 \%$ respondents above 1.500 EUR. Mostly household size is three to five people comprising $62,3 \%$ of respondents surveyed. The majority of respondents (71.3\%) tends to buy organic food at least one per week.

\section{Results and Discussion}

Moderated regression analysis (MRA) is used to detect the moderating effects of organic food subjective knowledge and organic food scepticism on the associated constructs depicted in the proposed model (Figure 1). Before MRA is conducted, we performed confirmatory factor analysis (CFA) to examine measurement model fit and construct validity. 


\section{Measurement Model Assessment}

Model fit indices indicate that the measurement model is satisfactory: $\chi^{2}(237)=$ 467.56, $\mathrm{p}<0.001, \chi^{2} / \mathrm{df}=1.972$; Comparative Fit Index (CFI) = 0.919; Tucker-Lewis In$\operatorname{dex}(\mathrm{TLI})=0.905$; the root mean square of error of approximation $($ RMSEA $)=0.069$; and the standardized root mean square residual $(\mathrm{SRMR})=0.053$. All standardized factor loadings are significant and greater than the recommended 0.50 threshold (Hair, Black, Babin, Anderson, \&Tatham, 2010). The composite reliability (CR) scores for all constructs were above the recommended cut-off value of 0.7 (Table 2.). The average variances extracted (AVE) ranges from 0.491 to 0.787 , exceeding the acceptable level of 0.5. Furthermore, the square root of AVE obtained for each construct was greater than the correlation of the construct with each of the remaining constructs (Table 3), indicating the discriminant validity of constructs of interest (Fornell \& Larcker, 1981).

Table 2: Scaling and measurement properties

\begin{tabular}{|c|c|c|c|}
\hline Construct and items & $\lambda$ (sig.) & $\mathrm{CR}$ & AVE \\
\hline Organic food subjective knowledge & & 0.737 & 0.500 \\
\hline I do not feel very knowledgeable about organic food. & $0.513 * *$ & & \\
\hline Compared to most other people, I know less about organic food. & $0.655 * *$ & & \\
\hline When it comes to organic food, I really don't know a lot. & $0.891 * *$ & & \\
\hline \multicolumn{4}{|l|}{ Subjective norms } \\
\hline My family would like me to buy organic food. & $0.748 * *$ & 0.851 & 0.593 \\
\hline My friends who influence my buying behavior think I should buy organic food products. & $0.824 * *$ & & \\
\hline Most people who influence what I do, think that I should buy organic food. & $0.876^{* *}$ & & \\
\hline People that are important to me would like me to buy organic food. & $0.606^{* *}$ & & \\
\hline Personal norms & & 0.571 & 0.403 \\
\hline Environmental protection is important to me when making food purchases. & $0.557 * *$ & & \\
\hline If I can choose between organic foods and conventional foods I prefer organic foods. & $0.704 * *$ & & \\
\hline Organic food scepticism & & 0.793 & 0.567 \\
\hline $\begin{array}{l}\text { Because claims ("healthy food," "environmentally friendly food," eco food) are } \\
\text { exaggerated, consumers would be better off if such claims on package labels in } \\
\text { advertising were eliminated. }\end{array}$ & $0.621 * *$ & & \\
\hline $\begin{array}{l}\text { Most claims on organic food package labels or in advertising are intended to } \\
\text { mislead rather than to inform consumers }\end{array}$ & $0.914 * *$ & & \\
\hline $\begin{array}{l}\text { I do not believe in most of the claims made on the organic food package labels or in } \\
\text { advertising. }\end{array}$ & $0.694 * *$ & & \\
\hline Attitude toward buying organic food & & 0.930 & 0.690 \\
\hline I think that buying organic food is interesting. & $0.700^{* *}$ & & \\
\hline I think that buying organic food is a good idea. & $0.796^{* *}$ & & \\
\hline I think that buying organic food is important. & $0.820 * *$ & & \\
\hline I think that buying organic food is beneficial. & $0.913^{* *}$ & & \\
\hline I think that buying organic food is wise. & $0.894 * *$ & & \\
\hline I think that buying organic food is favorable & $0.846^{* *}$ & & \\
\hline
\end{tabular}


Table 3: Discriminant validity of constructs

\begin{tabular}{|l|l|c|c|c|c|c|}
\hline \multicolumn{1}{|c|}{ Code } & \multicolumn{1}{c|}{ Construct } & SOFK & SN & PN & OFSCEPT & OFBA \\
\hline SOFK & $\begin{array}{l}\text { Subjective organic food } \\
\text { knowledge }\end{array}$ & $\mathbf{0 . 7 0 4}$ & & & & \\
\hline SN & Subjective norms & 0.052 & $\mathbf{0 . 7 7 0}$ & & & \\
\hline PN & Personal norms & 0.307 & 0.223 & $\mathbf{0 . 6 3 5}$ & & \\
\hline OFSCEPT & Organic food scepticism & -0.131 & 0.096 & -0.038 & $\mathbf{0 . 7 5 3}$ & \\
\hline OFBA & $\begin{array}{l}\text { Attitide toward buying } \\
\text { organic food }\end{array}$ & 0.116 & 0.408 & 0.611 & -0.047 & $\mathbf{0 . 8 3 1}$ \\
\hline
\end{tabular}

Note. The diagonal elements represent the square-root average variance extracted (AVE) by the construct. Offdiagonal elements show the correlations between constructs

\section{Moderated Regression Analysis}

Table 4 summarizes the results of the estimations of direct effects of the proposed model (Model 1), the direct effects with control variables (Model 2) and the moderating effects with control variables (Model 3). The expected positive relationship between subjective norms and consumer attitudes toward buying organic food was supported. As shown in Table 4 (Model 1), the coefficient was positive and highly significant ( $\beta=$ $0.344 ; \mathrm{p}<0.01)$. Therefore, hypothesis $\mathrm{H} 1$ is fully supported in this empirical study. Similarly, the effect of personal norms on consumer attitude toward buying organic food was positive and highly significant $(\beta=0.329 ; \mathrm{p}<0.01)$. The findings support hypothesis $\mathrm{H} 2$. We tested hypotheses H3a, H3b, H4a, and H4b with Model 3, which includes two interaction terms of subjective organic food knowledge and two interaction terms of organic food scepticism. The Model 3 showed that coefficient corresponding to H3a as significant at the level of $5 \%$ and had the unexpected positive sign $(\beta=0.0909 ; \mathrm{p}<$ 0.05 ). This result suggests that consumers with a higher level of subjective norms are more likely to hold a more positive attitude toward organic food purchases if they have a higher level of organic food knowledge. Moreover, the coefficient corresponding to H3b was insignificant and had the unexpected negative sign ( $\beta=-0.0301$; ns.). This results indicate that the relationship between personal norms and consumer attitude toward buying organic food is not moderated by subjective organic food knowledge. Therefore, hypotheses H3a and H3b were not supported. Similarly, we used Model 3 to test hypotheses $\mathrm{H} 4 \mathrm{a}$ and $\mathrm{H} 4 \mathrm{~b}$. The results supported hypothesis $\mathrm{H} 4 \mathrm{a}$ but not hypothesis $\mathrm{H} 4 \mathrm{~b}$. The coefficient corresponding to $\mathrm{H} 4 \mathrm{a}$ was significant and had the expected negative sign $(\beta=-0.0138 ; p<0.01)$. This finding indicates that that positive effect of subjective norms on consumer attitude toward buying organic food becomes weaker for those consumers who have a high level of consumer scepticism. However, H4b was not supported s the coefficient was not significant ( $\beta=0.846$, ns.). This means that the relationship between personal norms and consumer attitude toward buying organic food is not moderated by organic food scepticism. 
Table 4: The results of moderated regression analysis: mail effects and moderating effects

\begin{tabular}{|c|c|c|c|}
\hline & $\begin{array}{c}\text { Model 1: OFBA } \\
\beta \text { (t-value) }\end{array}$ & $\begin{array}{c}\text { Model 2: OFBA } \\
\beta \text { (t-value) }\end{array}$ & $\begin{array}{c}\text { Model 3: OFBA } \\
\beta \text { (t-value) }\end{array}$ \\
\hline Subjective norms & $0.344\left(6.43^{* * *}\right)$ & $0.346(0.640 * * *)$ & $0.442(1.55)$ \\
\hline Personal norms & $0.329(5.45 * * *)$ & $0.344(5.45 * * *)$ & $0.111(0.36)$ \\
\hline Subjective organic food knowledge & $0.000840(-0.01)$ & $-0.0386(-0.62)$ & $-0.346(-1.36)$ \\
\hline Organic food scepticism & $0.0318(0.55)$ & $0.0836(1.43)$ & $0.290(1.09)$ \\
\hline Gender & & $0.335(1.86)$ & $0.332(1.96)$ \\
\hline Age & & $0.0379(0.22)$ & $-0.0350(-0.22)$ \\
\hline Education & & $-0.132(-0.074)$ & $-0.134(-0.80)$ \\
\hline Household's size & & $-0.333(-1.82)$ & $-0.387(-2.24 *)$ \\
\hline $\begin{array}{l}\text { Subjective organic food knowledge x Subjective } \\
\text { norms }\end{array}$ & & & $0.0909\left(2.26^{*}\right)$ \\
\hline Subjective organic food knowledge $\mathrm{x}$ Personal norms & & & $-0.0301(-0.74)$ \\
\hline Organic food scepticism x Subjective norms & & & $-0.0138(-3.31 * *)$ \\
\hline Organic food scepticism x Personal norms & & & $0.0846(1.78)$ \\
\hline Constant & $1.75(3.54 * * *)$ & $1.5(3.00 * * *)$ & $2.738(1.62)$ \\
\hline Adjusted $\mathrm{R}^{2}$ (Percent) & 31.0 & 35.0 & 43.0 \\
\hline Note: ${ }^{* * * *} p<0.001 ;{ }^{* *} p<0.01 ;{ }^{*} p<0.05$ & & & \\
\hline
\end{tabular}

Figure 2: Interaction effects of SOFK on the subjective norms - OFBA link

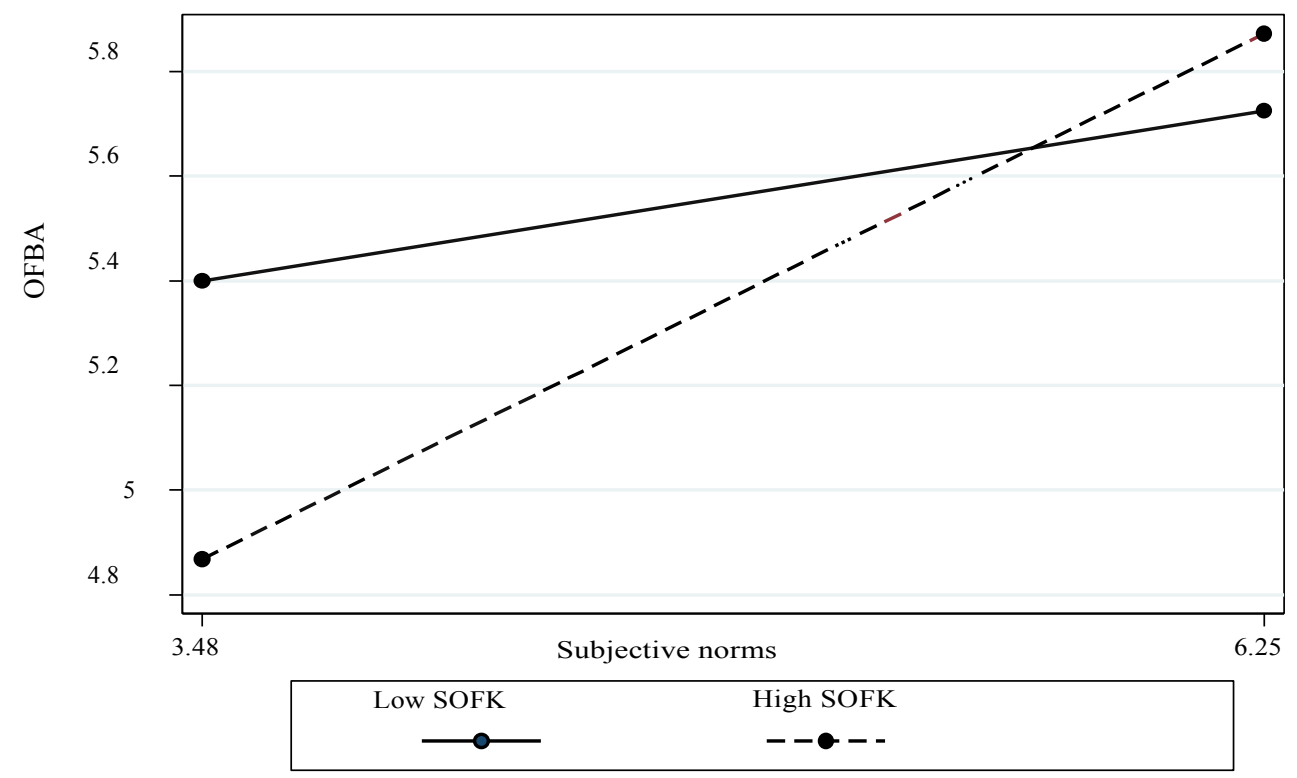


Figure 3: Interaction effects of OFSCEPT on the subjective norms - OFBAT link

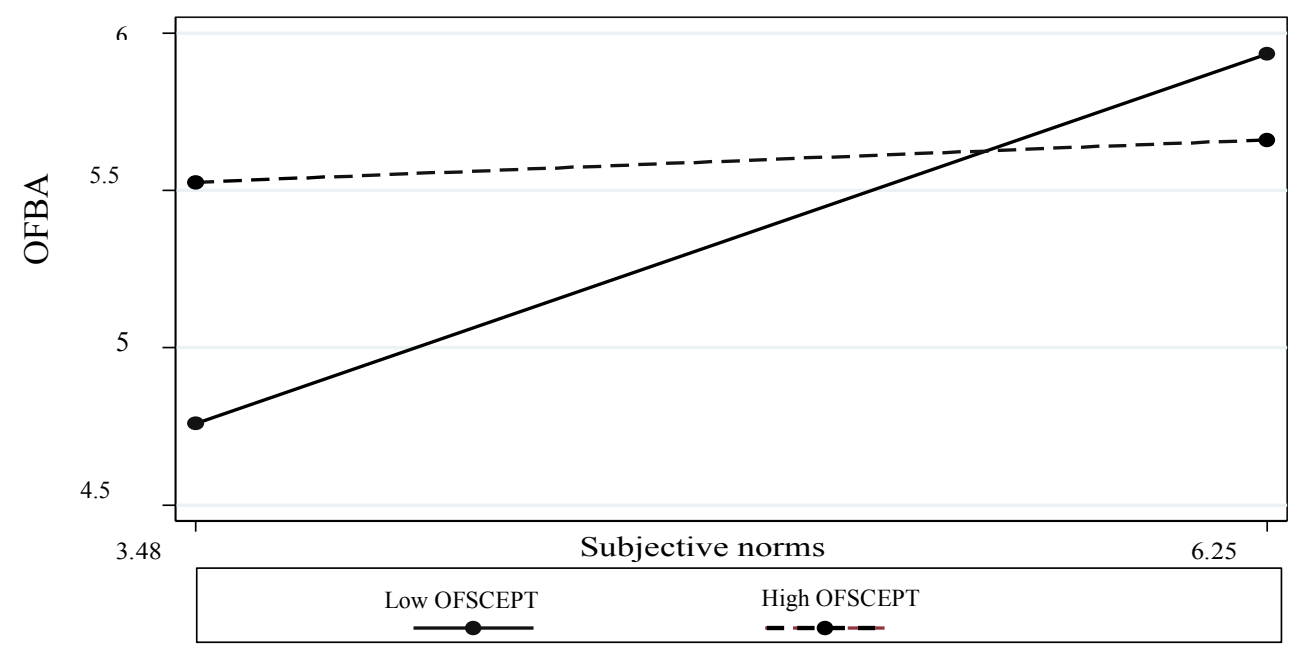

To further explore the nature of the significant moderating influence of organic food scepticism and subjective organic food knowledge on the norms-attitude link, we plotted the interaction effects (Figure 2 and Figure 3).

\section{Conclusion}

The findings of this study provide valuable implications for scholars, marketers, and policy-makers who are interested in promoting the widespread adoption of organic food. With consumer scepticism gaining momentum worldwide, the current study findings provide empirical evidence that organic food scepticism does have a moderating effect on the relationship between subjective norms and consumer attitude toward buying organic food in the context of an emerging economy. Explicitly, the results confirmed that lower the scepticism toward organic food, the stronger is the effect of subjective norms on consumer attitude toward buying organic food. These findings suggest that reducing the scepticism toward organic food claims can enhance the link between subjective norms and consumer attitude toward buying organic food. Thus, marketing managers should take endeavors to convince sceptical consumers that organic food claims are truthful and genuine. For instance, producers and marketers could provide product samples, which will enhance consumers' multisensory experience and help them to overcome their scepticism toward organic food claims. Also, producers should work with independent bodies, such as public authorities and NGOs, that certify organic food claims and award organic food la- 
bels (e.g.,"all natural, "100\% natural"“",100\% organic"). Since consumers are usually sceptical of claims made by producers and marketers, the approval from the independent body can enhance the credibility of organic food claims and reduce scepticism toward organic food (Fenko, Kersten \& Bialkova, 2016).

Contrary to our expectations, the findings of this study showed that subjective organic food knowledge positively moderates the subjective norms-organic food buying attitude. Thus, enhancing consumer's knowledge about organic food through diversified channels (e.g. TV, newspapers, magazines, websites, published/research reports, and seminars and workshops) should be the important task for the government, organic food producers, certifiers, and research institutions. Given the strong effect of subjective norms on consumer attitude toward buying organic food, a wordof-mouth strategy would be a useful marketing strategy in forming more favorable attitudes toward organic food purchases.

Furthermore, the so-called "star power" of celebrity endorsement (i.e., well-known TV chefs, famous movie stars, etc.), can be an effective marketing strategy in creating more positive (favorable) consumer attitude toward buying organic food. From a public policy perspective, policy-makers should implement activities and measures to alleviate consumer scepticism toward organic food claims. For instance, policy-makers could focus on regulatory policy and actions that will reduce consumer scepticism toward organic food (e.g., penalties for producers/firms for using false or misleading organic food claims, introducing the appropriate, reliable organic food labeling, etc.).

This study has several limitations. Although we controlled for the possible effect of the demographic characteristic on consumer attitude toward buying, the sample used in this study is not representative of the population. More systematic research is needed into the effects of various consumer characteristics on consumer attitude toward buying organic food, including food neophobia, food-related lifestyles, health concerns, etc. Also, the convenience sampling method suffers from common methods bias (CMB) and nonresponse bias. Future research can use the actual behavior (i.e. actual organic food purchases) as the outcome variable to eliminate the CMB issue. This study provides observations that link norms (subjective and personal) with a consumer attitude toward buying organic food by including two moderating variables (subjective organic food knowledge and organic food scepticism). Future research should extend the scope of the present study by adding more situational factors and/ or by using a multilevel design (e.g., buyers vs. non-buyers of organic food).

\section{REFERENCES}

Aertsens, J., Verbeke, W., Mondelaers, K., \& van Huylenbroeck, G. (2009). Personal determinants of organic food consumption: A review, British Food Journal, Vol. 111 (10), 1140-1167. DOI: 10.1108/00070700910992961. 
Ajzen, I. (1991). The theory of planned behavior, Organizational Behavior and Human Decision Processes, 50(2), 179-211. DOI: 10.1016/0749-5978(91)90020-T.

Ajzen, I., \& Fishbein, M. (1980). Understanding attitudes and predicting social behaviour. Englewood Cliffs, NJ: Prentice-Hall

Alibabic, V., Jokic, S., Mujic, I., Rudic, D., Bajramovic, M., \& Jukic, H. (2011). Attitudes, behaviors, and perception of consumers' from northwestern Bosnia and Herzegovina toward food products on the market, Procedia - Social and Behavioral Sciences, 15, 2932-2937. DOI: 10.1016/j. sbspro.2011.04.217.

Arvola, A., Vassallo, M., Dean, M., Lampila, P., Saba, A., Lähteenmäki, L. \& Shepherd, R. (2008). Predicting intentions to purchase organic food: The role of affective and moral attitudes in the Theory of Planned Behaviour. Appetite, 50 (2/3), 443-454. DOI: 10.1016/j.appet.2007.09.010

Brucks, M. (1985). The effects of product class knowledge on information search behaviour, Journal of Consumer Research , 12(1), 1-16. DOI: 10.1086/209031.

Cerjak, M., Mesić, Ž., Kopić, M., Kovačić, D., \& Markovina, J. (2010). What motivates consumers to buy organic food: Comparison of Croatia, Bosnia Herzegovina, and Slovenia, Journal of Food Products Marketing, 16(3), 278-292. DOI: 10.1080/10454446.2010.484745.

Fenko, A., Kersten, L., Bialkova, S., \& Bialkova, S. (2016). Overcoming consumer scepticism toward food labels: The role of multisensory experience, Food Quality and Preference, 48(A), 81-92. DOI: 10.1016/j.foodqual.2015.08.013.

Flynn, L. R., \& Goldsmith, R. E. (1999). A short, reliable measure of subjective knowledge. Journal of Business Research, 46(1), 57-66. DOI: 10.1016/S0148-2963(98)00057-5

Fornell, C., \& Larcker, D. F. (1981). Structural equation models with unobservable variables and measurement error: algebra and statistics., Journal of Marketing Research, 18(3), 382-388. DOI: $10.2307 / 3150980$.

Goh S.K., \& Balaji M.S. (2016). Linking green skepticism to green purchase behavior, Journal of Cleaner Production, Vol. 131, 629-638. DOI: 10.1016/j.jclepro.2016.04.122.

Golob, U., Kos Koklic, M., Podnar, K., \& Zabkar, V. (2018). The role of environmentally conscious purchase behaviour and green scepticism in organic food consumption. British Food Journal, 120(10), 2411-2424. DOI: 10.1108/BFJ-08-2017-0457.

Guagnano, G., Stern, P. C., \& Dietz, T. (1995). Influences on attitude-behavior relationships: A natural experiment with curbside recycling. Environment and Behavior, 27(5), 699-718. DOI: 10.1177/0013916595275005.

Hair, J., Black, W. C., Babin, B. J., \& Anderson, R. E. (2010). Multivariate data analysis (7 $7^{\text {th }}$ ed.). Upper Saddle River, New Jersey: Pearson Education International.

Hynes, N., \& Wilson, J. (2016), I do it, but don't tell anyone! Personal values, personal and social norms:: can social media play a role in changing pro-environmental behaviours?, Technological Forecasting and Social Change, 111, 349-359. DOI: 10.1016/j.techfore.2016.06.034.

Hughner, R. S., McDonagh, P., Prothero, A., Shultz, C. J., \& Stanton,NA J. (2007). Who are organic food consumers? A compilation and review of why people purchase organic food, Journal of Consumer Behaviour, Vol. 6, 1-17. DOI: 10.1002/cb.210.

Kaj P.N. M. and Ad Th.H. Pruyn (2003) . Consumer skepticism toward new products. in E - European Advances in Consumer Research Volume 6, eds. Darach Turley and Stephen Brown, Provo, UT : Association for Consumer Research, Pages: 351-358.

Klöckner, C. A., \& Ohms, S. (2009), The importance of personal norms for purchasing organic milk, British Food Journal, 111(11), 1173-1187. DOI: 10.1108/00070700911001013.

Meyer-Höfer, M., Nitzko, s., \& Spiller, A. (2015). Is there an expectation Gap? Consumers' expectations towards organic. British Food Journal, 117(5), 1527-1546. DOI: 10.1108/BFJ-07-20140252 . 
Obermiller, C., \& Spangenberg, E. R. (1998). Development of a scale to measure consumer skepticism toward advertising, Journal of Consumer Psychology, 7(2), 159-186. DOI: 10.1207/ s15327663jcp0702_03.

Onwezen, M. C., Antonides, G., \& Bartels, J. (2013). The norm activation model: An exploration of the functions of anticipated pride and guilt in pro-environmental behaviour. Journal of Economic Psychology, 39, 141-153. DOI: 10.1016/j.joep.2013.07.005.

Padel. S., \& Foster, C. (2005). Exploring the gap between attitudes and behaviour: Understanding why consumers buy or do not buy organic food, British Food Journal, 107(8), 606-625. DOI: 10.1108/00070700510611002

Park, C.W., Maclnnis, D. J., Priester, J. R., Eisingerich, A. B., \& Iacobucci, D. (2010). Brand attachment and brand attitude strength: Conceptual and empirical differentiation of two critical brand equity drivers. Journal of Marketing, 74(6), 1-17. DOI: 10.1509/jmkg.74.6.1.

Petljak, K., Stulec, I., \& Renko. S. (2017). Consumer's willingness to pay more for organic food in Croatia, Ekonomski vijesnik - Review of Contemporary Entrepreneurship, Business, and Economic Issues, 30(2), 441-465.

Pieniak, Z., Aertsens, J. \& Verbeke, W. (2010). Subjective and objective knowledge as determinants of organic vegetables consumption. Food quality and preference, 21(6), 581-588. DOI: 10.1016/j. foodqual.2010.03.004

Schwartz, S.H. (1977). Normative influences on altruism. In Berkowitz, L. (Ed.). Advances in Experimental Social Psychology, Academic Press, New York, NY.

Schwartz, S. H. \& Howard, J. A. (1981). A normative decision-making model of altruism, In: P. J. Rushton and R. M. Sorrentino, Eds., Altruism and Helping Behavior: Social, Personality, and Developmental Perspectives, (pp. 189-211), Lawrence Erlbaum, Hillsdale.

Skarmeas, D., \& Leonidou, C. N. (2013). When consumers doubt, watch out! The role of CSR scepticism, Journal of Business Research, 66(10), 1831-1838. DOI: 10.1016/j.jbusres.2013.02.004.

Tarkiainen, A., \& Sundqvist, S. (2005). Subjective norms, attitudes and intentions of Finnish consumers in buying organic food, British Food Journal, 107(11), 808-822. DOI: 10.1108/00070700510629760.

Thøgersen, J. (2009), The motivational roots of norms for environmentally responsible behavior, Basic and Applied Social Psychology, 31(4), 348 -362. DOI: 10.1080/01973530903317144.

Thøgersen, J. (2002), Promoting green consumer behavior with eco-labels, in Dietz, T., Stern, P. (Eds.), New tools for environmental protection: Education, information, and voluntary measures (pp. 83-104). Washington, DC: National Academy Press.

Yazdanpanah, M., \& Forouzani, M. (2015), Application of the Theory of Planned Behaviour to predict Iranian students' intention to purchase organic food, Journal of Cleaner Production, 107, 342-352. DOI: 10.1016/j.jclepro.2015.02.071.

Willer, H., \& Lernoud, J. (2017). TheWorld of Organic Agriculture: Statistics and Emerging Trends 2017, Research Institute of Organic Agriculture (FiBL) and IFOAM-Organics International, Bonn.

Zagata, L. (2012), Consumers' beliefs and behavioral intentions towards organic food. Evidence from the Czech Republic, Appetite, 59(1), 81-89. DOI: 10.1016/j.appet.2012.03.023 